
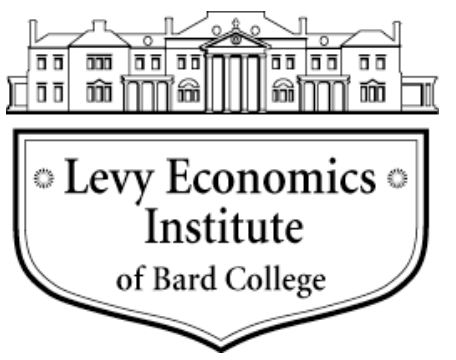

Working Paper No. 705

\title{
What Do Poor Women Want? Public Employment or Cash Transfers? Lessons from Argentina
}

by

\author{
Pavlina R. Tcherneva \\ Levy Economics Institute of Bard College
}

February 2012

The Levy Economics Institute Working Paper Collection presents research in progress by Levy Institute scholars and conference participants. The purpose of the series is to disseminate ideas to and elicit comments from academics and professionals.

Levy Economics Institute of Bard College, founded in 1986, is a nonprofit, nonpartisan, independently funded research organization devoted to public service. Through scholarship and economic research it generates viable, effective public policy responses to important economic problems that profoundly affect the quality of life in the United States and abroad.

\author{
Levy Economics Institute \\ P.O. Box 5000 \\ Annandale-on-Hudson, NY 12504-5000 \\ http://www.levyinstitute.org
}

Copyright (C) Levy Economics Institute 2012 All rights reserved

ISSN 1547-366X 


\begin{abstract}
The literature on public employment policies such as the job guarantee (JG) and the employer of last resort (ELR) often emphasizes their macroeconomic stabilization effects. But carefully designed and implemented policies like these can also have profound social transformative effects. In particular, they can help address enduring economic problems such as poverty and gender disparity. To examine how, this paper will look at the reform of Argentina's Plan Jefes into Plan Familias. Plan Jefes was the hallmark stabilization policy of the Argentine government after the 2001 crisis. It guaranteed a public sector job in a community project to unemployed male and female heads of households. The vast majority of beneficiaries, however, turned out to be poor women. For a number of reasons that are explored below, the program was later reformed into a cash transfer policy, known as Plan Familias. The paper examines this reform in order to evaluate the relative impact of such policies on some of the most vulnerable members of society; namely, poor women. An examination of the Argentine experience based on survey evidence and fieldwork reveals that poor women overwhelmingly want paid work opportunities, and that a policy such as the JG or the ELR cannot only guarantees full employment and macroeconomic stabilization, but it can also serve as an institutional vehicle that begins to transform some of the structures and norms that produce and reproduce gender disparities. These transformative features of public employment policies are elucidated by turning to the capabilities approach developed by Amartya Sen and elaborated by Martha Nussbaum - an approach commonly invoked in the feminist literature. This paper examines how the access to paid employment can enhance what Sen defines as an individual's “substantive freedom.” Any policy that fosters genuine freedom begins with an understanding of what the targeted population (in this case, poor women) wants. It then devises a strategy that guarantees that such opportunities exist and removes the obstacles to accessing these opportunities.
\end{abstract}

Keywords: Capabilities Approach; Employer of Last Resort; Job Guarantee; Basic Income; Cash Transfers; Public Employment; Gender Inequality; Poverty; Plan Jefes; Plan Familias; Argentina

JEL Classification: B54, D02, D13, D31, D63, E24, E26, E62, E65, H31, H41, H53, I38 


\section{INTRODUCTION}

Much of the literature on direct job creation, and specifically that on the Employer of Last Resort (ELR), over the last decade and a half has focused on the macroeconomic benefits of full employment policies (e.g., Mosler 1997-98; Wray 1998). Some of the literature examines the countercyclical features of the buffer stock employment models and their respective pricestabilization mechanisms (e.g., Mitchell 1998). Various models and simulations have examined these claims (Fullwiler 2003, 2005; Majewski 2004), while others have evaluated the relative macroeconomic advantages of direct job creation policies over alternative fiscal policies, such as basic income guarantees, cash transfers to households, and direct subsidies and contracts to businesses (Mitchell and Watts 2004; Tcherneva 2006, 2009, 2012).

A second line of research has illustrated how employment guarantee policies can enhance social justice by securing the right to work, as outlined by the Universal Declaration of Human Rights (Harvey 1995; Wray and Forstater 2004). Scholars have examined the effectiveness of programs such as the National Rural Employment Guarantee Act (NEGRA), which was instituted on these very same humanitarian principles and has specifically targeted the problem of endemic poverty in India (e.g., Hirway 2006.)

Several studies of Argentina's public employment program, Plan Jefes, which was modeled after the ELR proposals developed in the US, have examined both the macroeconomic stabilization effects of this program as well as the benefits delivered to its participants, especially women (Kostzer 2008, Tcherneva 2005; Tcherneva and Wray 2005a,b,c,d). This paper builds upon this research and explores how public employment schemes help address women's concerns and gender disparities in ways that alternative fiscal policies like cash transfers do not. The example of a cash transfer policy that will be examined in this paper is Argentina's Plan Familias. ${ }^{1}$

Argentina's economic success has been widely attributed to the social and economic reforms that took place after the crisis in 2001. The hallmark of the crisis resolution package in 2002 was a job guarantee program for unemployed heads of households known as Plan Jefes, which was later reformed into an income support policy for poor women only, called Plan Familias. Though the latter was initiated during Nestor Kirchner's presidency, it became the

\footnotetext{
${ }^{1}$ Such policies exist elsewhere in Latin America: such as Oportunidades in Mexico, Bolsa Famila in Brazil, Fundación de la Familia in Chile, and Familias en Acción in Colombia.
} 
signature social policy of his wife, Cristina Fernandez de Kirchner, who succeeded him in 2008. Plan Familias was among the policies credited with Fernandez’s popularity and success as president. Although Plan Familias was itself gradually phased out and eliminated by 2010, it is important to reflect on how it evolved out of its predecessor, Plan Jefes, and what benefits the programs had delivered to their beneficiaries.

Plan Familias aimed to offer more generous income support to poor women with many children who participated in Jefes projects, but without the requirement to work. In some ways, it was similar to a child allowance policy, but it was not conceived as such. Indeed Argentina has a different program today called Asignación Universal por Hijo (AUH) that provides universal child support to all. Instead, Plan Familias was conceived as a policy that would replace the employment safety-net women enjoyed under Plan Jefes with a cash transfer support, largely on the grounds that poor women with many children should not be participating in active labor market government policies such as Plan Jefes. Understanding the peculiar history of this transformation in social policy in Argentina from an employment guarantee to an income guarantee policy would provide the necessary context that allows us to evaluate the impact of Plan Familias on poor women. It will be argued that the transformation of Plan Jefes into Plan Familias represented a step backward for women in two decisive ways.”

First, while it offered income support, it removed a number of the benefits women reaped from working outside the home and from actively participating in the community. Second, the cash transfer was designed on the basis of traditional views about gender roles that only reinforced prevailing gender stereotypes. Though Plan Familias aimed to target the poorest and most vulnerable women participating in Plan Jefes, survey evidence suggests that it is precisely this group that reports the greatest benefits from being involved in public employment. Before I discuss this evidence and evaluate the two programs, it is important to examine broadly the gender effects of public employment schemes à la ELR to those of nonwage income subsidies to women. This will be done by invoking the capabilities approach developed by Amartya Sen and Martha Nussbaum to illustrate how public employment schemes are uniquely suited to enhancing individuals’ substantive freedoms and life chances.

The starting premise of this paper is that paid work matters to women. Women want and value the opportunity to work outside the home, and public employment has a special role to play in achieving this goal. Public service employment à la ELR can enhance individual well- 
being and, thus, the role of fiscal policy in the present context extends beyond the goal of securing full employment and economic stability.

There has been a long debate about the relative benefits women have reaped from increased access to paid work. ome have argued that globalization, growth, and development have fostered their participation in labor markets, giving them access to paid employment, income, and command over material resources — which in turn has helped them to achieve greater gender equality over the years (e.g., Inglehart and Norris 2003; Walby 1997, 2002; Çagatay and Ertürk 2004). Others contend that the progress is dubious, as indicated by the visible feminization of precarious work and poverty; women often take part-time employment that offers little or no benefits, have fewer chances for promotion, or end up working in the lowwage service and export sectors (Çagatay and Ozler 1995; Seguino 1997; Standing 1999; Finnoff and Jayadev 2006). ${ }^{2}$

This mixed bag of evidence is not surprising in light of the fact that globalization, growth, and development have not been accompanied by policies for full employment, and that the neoliberal attack on state intervention has resulted in declining safety-nets, more unstable forms of employment, and race-to-the bottom competitive strategies that have eroded wages, benefits, labor conditions, and job security. Thus, with the retreat of pro-employment policies, labor markets, in general, and private sector work, in particular, have become increasingly more precarious for both men and women. Women, however, have been disproportionately affected by these trends. The demands on women within the household in the form of unpaid work have also prevented them from vying for the more stable forms of employment available to men. Some evidence suggests that with the increase in labor market participation, particularly in the developing world, the intensity and burden of unpaid work have also increased (Antonopolous 2008). ${ }^{3}$

Policies such as the ELR can offer a genuine alternative to unstable and often exploitative private sector work (Tcherneva 2006). And to the degree that women disproportionately suffer from precarious low-wage private sector employment, they can also

\footnotetext{
${ }^{2}$ The devastating effects of neoliberal structural policies on women have been well documented (see, for example, Beneria and Feldman 1992). Seguino (1997) has also examined from a macro perspective how globalization and export-led developmental strategies have contributed to the increasing marginalization of women.

${ }^{3}$ There are considerable variations in unpaid work across the developed and developing world, where women pick up from a few minutes to up to 5 hours more unpaid responsibilities per day than men. Two notable exceptions are Denmark and the Netherlands, where men perform, on average, eight more minutes of unpaid work per day than women (Antonopoulos 2008, 8-21).
} 
disproportionately benefit from stable living-wage public sector jobs offered by the ELR. But the ELR is not only a policy that guarantees full employment; it is an institutional vehicle that could begin to transform some of the structures and norms that produce and reproduce gender disparities (Ibid.). While job guarantee programs redress indirectly the precarious nature of labor markets, a gender-informed ELR can also directly remove the obstacles to paid work that women face by socializing some of the costs of unpaid work, by enhancing public infrastructure and time-saving technologies, and by offering requisite training and a meaningful work experience to all. $^{4}$

In addition to providing income and assets to women, ELR offers other intangible benefits. First, it can help redefine the meaning of work by valuing care, social production, usefulness, and the environment (Tcherneva 2006; 2009). Second, because women not only benefit from these services, but actively participate in and contribute to their production, individual empowerment, civic engagement, and participatory democracy are enhanced. Third, ELR can serve as an institutional vehicle for collective action to address the needs of the individual participants and community at large. Income support programs do not deliver those benefits, and therefore do not have the potential transformative properties of job guarantee schemes. $^{5}$

Thus, as we compare the relative merits of Plan Jefes and Plan Familias, it is important to emphasize that fiscal policies such as ELR or the Job Guarantee carry benefits beyond those of full employment. They can potentially serve as an agent of change that erodes long-standing structures and social mores that perpetuate gender disparities. Some of these transformative features of ELR can be illuminated by turning to the capabilities approach developed by Sen (1999) and elaborated by Nussbaum (1999, 2003), an approach commonly invoked in the Feminist literature. This paper relates the definition of "substantive freedom" to the access to paid employment to make the case that, not only must obstacles be removed, but opportunities must be guaranteed in order to produce genuine freedom to participate in paid work. Furthermore, access to guaranteed public sector employment could be the first step toward enhancing substantive freedoms and individual life chances.

\footnotetext{
${ }^{4}$ For details on how ELR alleviates unpaid work see Antonopoulos 2007.

${ }^{5}$ It could be argued that by providing a cash transfer to women, fiscal policy recognizes the importance of the unpaid work women carry, and thus can help expand our views of what constitutes useful work. I argue that by socializing some of these costs and incorporating them explicitly in the public sector, we can make better progress in blurring the already problematic distinction between productive and unproductive work.
} 
When looking at Argentina's experience, there is reason to believe that Plan Familias did not offer comparable improvements to the lives of women as were provided under Plan Jefes. For this reason, it is best to view Plan Familias as a policy that helped children, rather than one that redressed gender disparities. To see why that might be that case, I will turn to the fieldwork and survey evidence that specifically deals with the attitudes of women and their personally-stated needs found in Tcherneva (2005), Tcherneva and Wray (2005a,b,c,d), Pastoret and Tepepa (2006) and Garzon de la Roza (2006). The data from the official household survey in Argentina (EPH), which many scholars use in evaluating Jefes, tells only part of the story. While fieldwork and more disaggregated survey evidence are essential for an adequate assessment of program impact on beneficiaries, there are unfortunately very few surveys of this kind.

\section{THE COMPLEX PROBLEM OF GENDER INEQUALITY}

The World Bank Global Monitoring Report 2007 reviews the progress toward achieving the Millennium Development Goals as set out by the 2002 Monterrey consensus, and identifies gender inequality as one of two areas where scant gains have been made. ${ }^{6}$ Gender equality and empowerment, specifically, are identified as two goals that merit increased efforts and attention. Gender equality is both a precondition for and contingent upon the availability of economic opportunities for all, the reduction of poverty, achievements in education, declines in child mortality, and overall economic and socioeconomic prosperity (World Bank 2007, xi). Because gender inequality is produced and reproduced by inequitable economic structures, alleviating it is a formidable challenge to policy makers. Thus, more and more scholars call for gender-aware budgeting, policy reforms, and other initiatives to specifically address gender disparities (e.g., Bakker 2002; Elson 2006). To inform the design of policy, the pressing need to collect more detailed and comprehensive time-use data has been singled out in particular (Antonopoulos 2008).

The 2007 World Bank Report identifies gender equality not necessarily in terms of equal outcomes for men and women, but in terms of equal opportunities to all; that is, the “opportunities that allow people to pursue a life of their own choosing and to avoid extreme

\footnotetext{
${ }^{6}$ The other area with meager progress is that of strengthening fragile states and providing them with resources, institutions, and capacity to meet basic human developmental needs and provide for its citizens.
} 
deprivations in outcomes” (World Bank 2007, 106). The report broadly identifies three types of equality: a) equality of rights, which are specified under both statutory or customary laws; b) equality of resources, which refers to the equal access to opportunity, human capital investment, productive resources, and markets; and c) equality of voice, which is often measured by the ability to participate in the political process and shape its outcomes (Ibid.).

As the World Bank 2007 report recognizes, while these three different types of equality usually refer to the household, market, and political spheres, respectively, they are intimately intertwined and interdependent. Thus, structures that perpetuate unequal outcomes are resilient as they reinforce one another. For this reason, breaking them down cannot occur with a single program but with an integrated gender-aware policy agenda.

Alleviating gender disparities necessarily requires addressing a wide array of problems. Some of the important issues are: 1) the disproportionate burden of unpaid work women carry within the household; 2) the greater relative shortage women face of overall paid employment opportunities and, specifically, of jobs offering a stable and parent-friendly environment; 3) the unequal access to education and training, including on-the-job training; 4) the divergent pay and promotion opportunities for women in the market place; 5) the dissimilar control over material resources, financial wealth, and legal property; and 6) the relative lack of female policy makers, to name only a few of the important issues. In other words, gender inequality is a complex phenomenon that requires a comprehensive approach. ${ }^{7}$

For all of these reasons, we cannot presume that public employment is the cure-all for gender equality in the market place. But we can expect public employment schemes to have a major advantage over income support programs in correcting some of the gender disparities that emerge from precarious work, unstable sources of income, inadequate access to paid work and on the job training, and the erosion of skill and human capital. Public employment schemes can serve as institutions for change and transformation that can be designed in a way to target specific policy objectives as they pertain to gender issues. They can provide training and education while guaranteeing employment opportunities to those who want to work outside of the home. They can build public assets and alleviate unpaid work by socializing some of the costs of care. They can allow participants to shape their work environment, enhance their community resources, and voice their concerns collectively through a public institution that

\footnotetext{
${ }^{7}$ Some quick impact initiatives have nonetheless been identified in the literature for speedy headway in reversing these trends (e.g., Grown 2006).
} 
exists to serve their interests and objectives. And, as explained in earlier research (Tcherneva 2005; Tcherneva and Wray 2005a,b,c,d), such examples already exist in Argentina, paving the way for achieving greater equality of rights, resources, and voice.

The decentralized, bottom-up design of the program, for example, has allowed women to launch and actively participate in their own work projects (Ibid.). It has allowed them to take initiative in addressing specific community needs: women actively participate in the provision of shelter and food services, organize massive clean-ups of landfills, and have launched recycling projects. The program has allowed them to start their own microenterprises, firms, and cooperatives. Thus, Plan Jefes offered women an income and work experience, and could also potentially increase household assets and wealth. ${ }^{8}$ Better survey work is needed to evaluate the prevalence of such examples, but there are indications that public funding, in some cases, served as an effective form of microcredit for women.

There are also indications that women who train on the job and gain experience in various projects can transcend traditional gender lines. In Jefes, some women worked as electricians, construction workers, carpenters, et al. (Pastoret and Tepepa 2006). Women were workers, supervisors, and political leaders. Women activists who managed Jefes projects had a direct representation in government. As noted earlier, new positions in the labor ministry were created for those activists to voice the needs of their constituents.

Women received basic training alongside their place of work. They helped rebuild the infrastructure of many neighborhoods, organized day care centers in close proximity, set up food kitchens, and assisted with after-school homework assignments and recreational activities for children-all examples of public projects that could collectively help alleviate the burden of unpaid work within the household. In Jefes, women had the opportunity to learn basic skills of food preparation, cleanliness standards, and health practices-which, along with the basic program eligibility requirements to enroll children in school and get the necessary vaccinations, were important improvements in their own lives and those of their families. Women reported that they liked to work, looked forward to working, and wanted to work longer hours (Ibid.; Tcherneva 2005; Tcherneva and Wray 2005d).

\footnotetext{
${ }^{8}$ I say potentially, because the program was reformed and phased out only a few years after its implementation. Thus it is impossible to evaluate the extent to which Jefes was able to increase household wealth, but for those women who were able start their own businesses through the program, Jefes had provided an opportunity to do so over the long run.
} 
These Jefes projects that were created were few, relative to the existing needs in the poor communities, or to the number of women (and men) who wanted to participate in the program (program participation was limited to one member per family). But they were indications that the institutional framework allowed for all of these functions to be implemented on a larger scale. Thus, it is important to design ELR programs not as a “workfare programs," but as institutions for social change and transformation. The transformative attributes of public employment schemes can be illuminated by examining them within the capabilities approach.

\section{A CAPABILITIES APPROACH TO PAID WORK}

Work matters, however broadly defined. Work empowers, enhances individual worth, and allows one to lead a richer life, gain new knowledge and skill, and contribute to self, family, and society. Work is life-affirming. While certain pursuits are solitary and individual, even they deliver benefits when performed as part of a greater community. ${ }^{9}$ In modern monetized societies, paid work matters, in particular. Not only does it deliver all the benefits above, but it supplies the mode by which most of those benefits are obtained (i.e., income). Paid work is an important and undeniable condition of contemporary life.

For the poor and marginalized men and women, however, work often means strictly a survival strategy; it is onerous, oppressive, and confining. Paid work for many is part of this survival strategy and is neither rewarding nor liberating. For women in particular, paid work can produce a “double shift” day, as they are compelled to enter formal or informal paid work to supplement the family income, while still carrying the burden of unpaid care in the household. Public policy, therefore, whatever its specific objective, is often rationalized by the need to liberate individuals from the repressive social conditions that prevent them from realizing their full potential and engage in meaningful work. In the context of the present research, this indicates that the goals of fiscal policy are greater than the specific objectives of economic stability and full employment; they ultimately deal with human well-being.

Improving human well-being begins when public policy ensures certain basic human rights. There are two distinct schools of thought on how fiscal policy can accomplish this. One

\footnotetext{
${ }^{9}$ Examples of such activities are artistic endeavors such as writing poetry, composing music, and painting. And indeed in the US, the New Deal explicitly included them as part of the public employment programs, which provided work and education for many jazz musicians and painters.
} 
argues in favor of guaranteeing a basic income support to all, the other for guaranteeing a paid employment opportunity. Both of these can be rationalized by the capabilities approach developed by Sen (1999), and elaborated by Nussbaum (1999), which emphasizes substantive freedoms and the minimum necessary conditions to enhance these individual substantive freedoms.

Sen defines substantive freedoms as "the capabilities - to choose a life one has reason to value” (Sen 1999, 74). To engage in any activity, he argues, individuals must not only have the functional capacity to do so, but also the substantial freedoms to act; i.e., the real opportunities to pursue one’s own objectives. Much observed inequality is a surface phenomenon-a manifestation — of underlying inequitable structures which have unequal "distribution of substantive freedoms and capabilities” (Ibid., 119). Nussbaum's elaboration of Sen’s substantive freedoms is rooted in the idea that men or women, irrespective of their location in the socioeconomic context, are individuals of equal dignity and worth (Nussbaum 1999, 57). The duty of the social reformer is to identify individual needs and then to universalize opportunities through redistributive policies that would enhance "human functioning." Human functioning is delimited by the kind of activities individuals wish to engage in. And to do so, certain basic conditions are necessary. Those essential conditions include life, bodily health and integrity, ability to live for and in relation to others, and control over one's environment, among others. In order, however, for individuals to control their environment, Nussbaum argues, both political and material control, including the "the right to seek employment on an equal basis with others" are key (Ibid., 42).

Income guarantee supporters suggest that a fundamental injustice in the world exists when some (e.g., wealthy heirs or otherwise privileged) are exempt from paid work for their livelihood, while others depend on a wage-paying job to survive. The best way to secure equal footing to all is to guarantee a minimum income to buy the basic necessary standard of living (Van Parijs 1991; Widerquist 1999).

Employment guarantee supporters argue that inequitable labor market structures and poverty are largely a function of a world in which full employment at a living wage is not guaranteed for all. In such a world, race-to-the-bottom competitive practices make employment more precarious, and push the most vulnerable into poorly paid, part-time work conditions in an unsafe environment. Public job guarantees are needed to ensure the right to work and to set a 
minimum standard for working conditions and pay. Employment guarantee programs are to be structured in a way to enhance individual opportunity and advance the public interest.

Whether basic incomes or job guarantees advance substantive freedoms more effectively depends in part on how we understand the meaning of Sen's substantive freedom. In my reading of Sen, three key factors must be present: 1) policies need to recognize what individuals want and value (recognize their "sense of self and self-evaluation” (Sen 1987, 32); 2) they need to provide those opportunities; and 3) they need to ensure that individuals can take advantage of those opportunities.

Those who favor income support schemes often argue that to enhance the capabilities of each individual, at a minimum, policy must guarantee the provision of a basic income. This minimum income threshold is a prerequisite for developing and pursuing the remaining capabilities. Sen, however, often emphasized that income is just one aspect of ensuring human well-being. He did not state that it was the minimum necessary condition. With respect to the problem of poverty, Sen explicitly recognized that income alone could not create the preconditions for poverty alleviation. When discussing famine prevention in particular, he has argued that policies which tie the provision of income to work or effort have been successful because individuals benefit from these programs due to advantages that are far broader than those from earning income alone (Sen 1999, 133). Similarly, in the case of Argentina, government surveys and other fieldwork show that income is but one reason-and among the least important ones-explaning why women liked their experiences in the Jefes program (see Figure 1). 
Figure 1 Reasons why participants are satisfied with the Jefes program

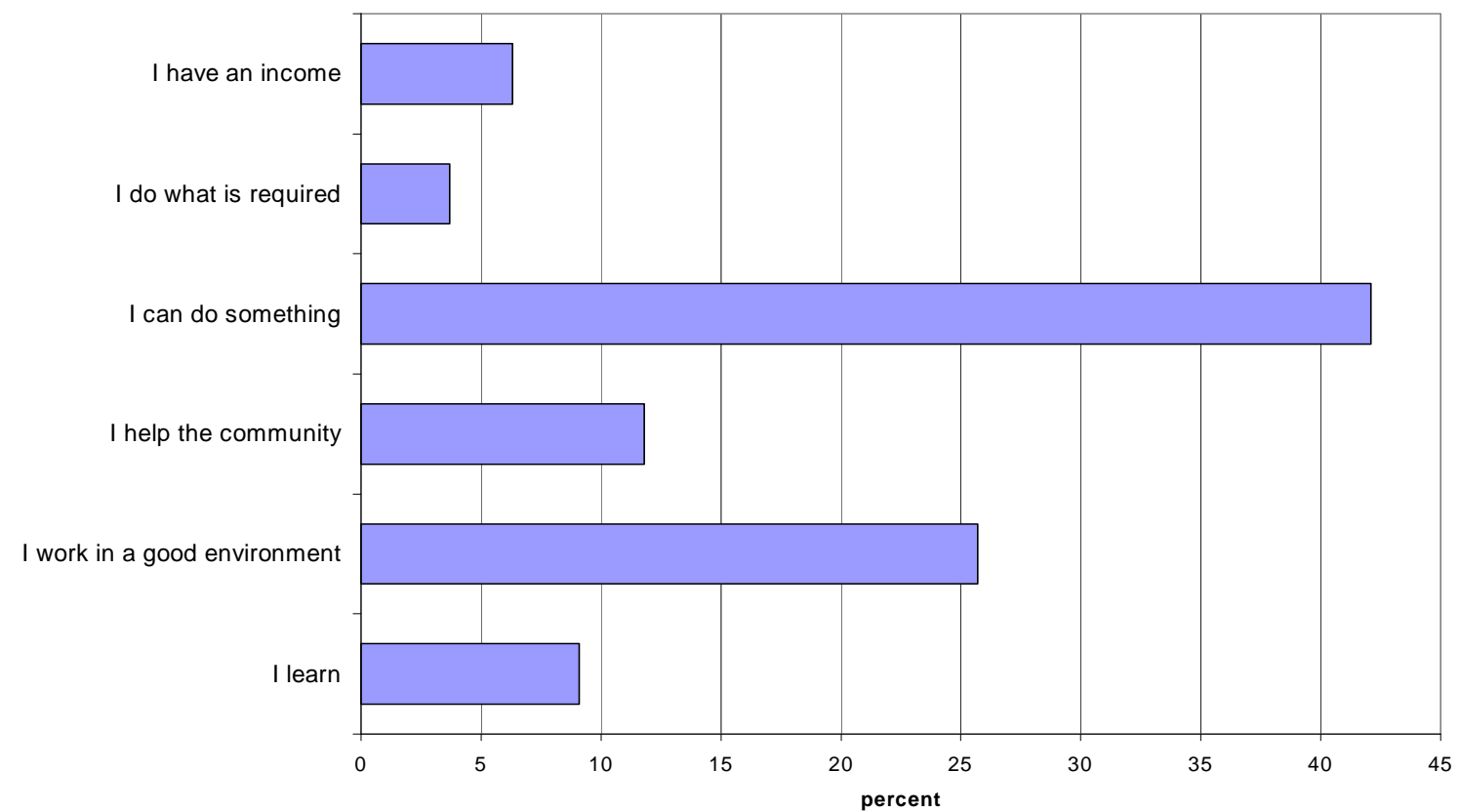

SOURCE: Ministry of Labor, Employment and Social Security, Argentina

More important than that, women reported that they wanted to work and overwhelmingly preferred income-paying public sector jobs to welfare checks of the same amount (see, also, Tcherneva 2005; Tcherneva and Wray 2005a,b,c,d). The subsequent reform, which removed the job guarantee and replaced it with income support alone through Plan Familias, failed to recognize that women wanted to participate in paid employment. The first of the three ingredients of substantive freedoms was, therefore, missing.

Sen and Nussbaum had long advocated policies that improve the social and economic power of women and challenge patriarchal views of women's place in society. In this respect, the ELR has one major advantage over income support schemes. The ELR can expand and enhance female agency in a way that women are treated not as "patients of development but as agents of development” (Koggel 2003, 166). Paid work from public service employment has the potential to provide the context which will allow women to transform the welfare state from a paternalistic to an empowering institution by giving women paid work opportunities with which to reshape their own destinies, especially if they are involved in the planning and organization of the projects. 
Additionally, what is perhaps obvious must be stated. Income support, coupled with education and training programs will not enhance well-being if unemployed women cannot reap the benefits of their training and education. Policies that increase employability but do not guarantee employment need not empower; but policies that guarantee a job are certain to encourage even the least educated person, who feels that s/he is being useful to society. Employability policies are highly desirable but, on their own, can be inadequate. The right to work must also be guaranteed.

Paid work matters, and it matters especially for female empowerment and gender equality. Using the capabilities approach and the three criteria of substantive freedom above, one can argue that fiscal policy must: 1) recognize that women want paid work; 2) guarantee the right to work to all; and 3) alleviate the obstacles to paid work.

Right-to-income policies, for example, which often rationalize the need for income guarantees (see, e.g., Standing 2008), do not have these three aspects. They hope to provide the financial resources to alleviate poverty and liberate women from onerous household work, but do not offer genuine opportunities for stable and non-precarious paid employment. ${ }^{10}$ Job guarantees can offer such an opportunity, but if they are not carefully designed, they may not alleviate the obstacles that prevent women from entering the market in the first place (e.g., care responsibilities). Thus, gender-aware job guarantees are essential, as they will explicitly tackle the nexus between paid and unpaid work that shapes inequitable labor market outcomes. ELR must be a paid work alternative that alleviates the unpaid work burden of women and removes one crucial obstacle to their participation in the labor market on the same terms as men.

But, as noted above, gender inequality is a pervasive and multi-dimensional problem that public employment cannot presume to resolve entirely. ELR can, however, redress some of the structural problems that produce and reproduce gender disparities, and it can also help erode, overtime, the paternalistic social mores that perpetuate inequitable power relations.

Elson (1995) has argued that gender stereotypes are reproduced in social hierarchies, structures, and ideologies. Gender stratified production for example reinforces such social mores-women's work is generally confined to the household, while men's work is considered

\footnotetext{
${ }^{10}$ Ironically, however, a basic guaranteed income would be able to alleviate the burden of household work and make room for other pursuits only if the recipient of the income can now find someone who is willing to perform these household chores for pay. Thus, by commodifying household work, the basic income proposal seems to suggest that the unpaid work burden can be alleviated by now making it 'paid' work. In short, the basic income proposal assumes that, as long as the minimum income is guaranteed, there would be a market solution to fill the need for care work provisioning.
} 
productive as it commands market valuation. Giving women greater access to and command over material resources will begin to erode some of these stereotypes. Access to paid work is a direct channel by which women can participate in mainstream market activities, extract income and assets from these activities, gain greater command over their material resources, and transition more easily to private and public sector work. The shift in the balance of material control will gradually wear down old psychological mores and gender stereotypes. Admittedly, cultural norms endure, and are toppled only with a significant lag after more equitable policies have been put in place. This is a considerable problem as expressly demonstrated in Argentina. The replacement of Plan Jefes by Plan Familias was originally motivated precisely because many of the women who entered into the Jefes program were considered to be "unemployable" and "too poor or socially vulnerable" to work. This tug of war between patriarchal attitudes about what is considered productive or unproductive work, and who is employable and who is not, retards genuine progress and pushes women back into the household, confining them to their traditional gender roles (more below).

With time, however, public employment policies can undermine inequitable structures and social mores. There is some evidence that suggests such an outcome. Seguino (2007) tests and finds support for the hypothesis that paid work erodes stereotypes that perpetuate gender inequality. By contrast, as Barbara Bergmann (1986) has argued, income support and welfare has the effect of reinforcing traditional gender roles and even reversing the advances women have made in society, in general, and in the workplace, in particular. Bergmann has strongly defended the right to work, which will allow women to use their education to achieve greater equality with men and to enrich their lives in general (Hartman 1998).

Income support programs often treat women as helpless, vulnerable, passive recipients of charitable state assistance. They often result in the creation of a whole system to "care" for these women, which effectively institutionalizes poverty. Public employment, by contrast, brings the community closer together, increases solidarity and common purpose, and empowers the poor to become active agents of change in their own lives.

Last but not least, public policy must be examined in the context of its broad macroeconomic results. Sen has argued that "the role of public expenditure in generating and guaranteeing many basic capabilities calls for attention; it must be considered along with the instrumental need for macroeconomic stability” (Sen 1999, 141; emphasis added). And while he did not speak of a job guarantee program, the ELR proposal is a very good candidate for a 
policy that generates and guarantees certain basic capabilities, advances substantive freedoms, and secures desirable macroeconomic results. The relative macroeconomic benefits of basic income and job guarantees have been evaluated in detail elsewhere (see Mitchell and Watts 2004; Tcherneva 2006, 2009). According to this literature, basic incomes (and by extension, massive cash transfers, in general) have a strong inflationary bias and may even prove to be hyper-inflationary. They erode the value of the currency, undermine incentives for labor market participation, and depress output and employment. These policies are likely to be, at a minimum, stagflationary. By contrast, ELR has a series of important macroeconomic stabilization features identified in the literature that cannot be found in basic income guarantee proposals (Ibid.).

Thus, not just income, but income from work, can establish a minimum threshold of capabilities while enhancing macroeconomic stability. In Tcherneva (2006, 2009), I have suggested that the best way to combine the laudable goals of basic income and job guarantees is to begin with "participation income," where the income provision is conditional on the participation of beneficiaries in and their contributions to the community (Atkinson 1995; Galston 2001; White 2003). Plan Jefes is one clear example of how the basic income support can be effectively coupled with public service work. Such a requirement to work within the community is crucial because it removes the macroeconomic problems of basic income guarantees, and offers a genuine institutional vehicle to begin targeting very specific needs and goals. The next question to examine is how Plan Jefes had promised to serve as an institutional vehicle for greater gender equality — a promise that bounced as a result of its hasty reform and replacement by Plan Familias.

\section{PLAN JEFES AND PLAN FAMILIAS AND THEIR IMPACT ON WOMEN}

Jefes was not designed specifically to deliver those benefits to women that we identified in our survey. In fact, the program was initially called Jefes de Hogar (i.e., male heads of households), and only after women enrolled in large numbers, was it renamed to Plan Jefes y Jefas de Hogar (plan for male and female heads of household). Although not by design, it did illustrate how public employment programs can advance women’s issues. Here, I will briefly summarize some of our fieldwork findings (Tcherneva 2005; Tcherneva and Wray 2005a,b,c,d), as well as those of two other similar surveys (Pastoret and Tepepa 2006; Garzón de la Roza 2006). I will then 
look at the reform of Plan Jefes, and specifically the justifications for the welfare component Plan Familias, to argue that this was not a reform that was designed with the wishes and desires of women participants in mind. I will argue that it was the poorest and least educated women (i.e., the most "vulnerable" according to government terminology) who seemed to have benefited the most from the job guarantee program.

\subsection{Paid Work, Poor Women, and Plan Jefes: Some Additional Evidence}

In our informal survey, every woman that we interviewed without exception wanted to work rather than receive a welfare check of equal amount (Tcherneva and Wray 2005a,b,c,d). During the second evaluation of Plan Jefes, the Ministry of Labor also found that many women were disappointed to return to inactivity as a result of being moved into Plan Familias (MTEySS 2005a). A third survey by Pastoret and Tepepa (2006) found that women who moved to Plan Familias, but whose Jefes community projects were not yet discontinued, kept going to work, even though they were now exempt from the work requirement and no longer qualified for participation in Jefes. They felt the need to be part of the community and to work outside of the home.

A separate survey conducted by Garzón de la Roza (2006) focused specifically on the impact of Plan Jefes y Jefas on poor women. Her study paid special attention to poor women's narratives and showed that their first exposure to paid work significantly boosted their selfperceptions, promoted collective and individual empowerment, and made important qualitative changes to their lives (Garzón de la Roza 2006, 8). Like Pastoret and Tepepa, Garzón de la Roza also found that the socialization of women's work increased the respect and recognition women received in their own families and in the community at large. The main finding of Garzón de la Roza's work was that even those policies that were initially implemented as crisis resolution tools would produce, overtime, important changes to poor women's lives (Ibid., 10).

Once the funding and materials were provided through Plan Jefes, poor women could actively participate in collectively addressing their own and their communities' needs. They set up food kitchens, shelters for the homeless, butcher shops, and day care centers (Tcherneva 2005; Tcherneva and Wray 2005d). They organized neighborhood water-rights groups, health cooperatives, and family violence centers (Garzón de la Roza 2006). Those who had lost the Jefes income once they were transitioned to Plan Familias during the reform often came back to work in the remaining Jefes projects as volunteers (Ibid.). Garzón de la Roza specifically finds 
that men, who were no longer able to find employment in the city and were compelled to join their neighbors in the community work projects, had expanded their views about family and work as a result of their "socialization with women and children and contact with other realities" within the impoverished neighborhoods (Garzón de la Roza 2006, 68). All workers reported that, by working in the community, they learned things they did not know before, and the experience opened their eyes to poverty and child destitution that they did not know existed (Ibid., 79). Pastoret and Tepepa (2006) also report that although some men saw Jefes as “women’s work”- e.g., public kitchens, day care centers, microenterprises-they did recognize that public work was important to these women, their families, and the community. Men participating in the program also felt that it had provided them with a "second family" (Ibid.).

Tcherneva and Wray and Pastoret and Tepepa find that women not only designed their own projects, but worked longer hours than what they were paid for. Pastoret and Tepepa also report that children were not considered by women to be a major impediment to participation in Jefes because relatives were involved in their care, and the children themselves were either enrolled in school or attended the public nurseries operated by Jefes. Many women also desired private sector work, but many felt humiliated when searching for these opportunities, either because they had a "bad experience" when looking for a job or because the only available private sector work was housekeeping in the informal sector, which was considered undignified (Ibid.). In Jefes, women felt that their work was respectable and respected. Like Tcherneva and Wray, Garzón de la Roza also found that the obstacles to work in the community were lack of enough funding and materials for the food kitchens or other social services, as well as poor infrastructure and inadequate equipment.

Female project leaders became central agents for the advancements of their communities' needs and interests. They felt empowered not only because of the responsibilities they carried, but also because of the respect they commanded among all members of the projects, including male workers (Garzón de la Roza 2006, 77). Pastoret and Tepepa (2006) found that Jefes y Jefas can be more than a community service project: in Lomas de Zamora (the region they surveyed), the Municipal Institute for Production, Labor and Trade Employment Office was a central institution that had launched an integrated approach to development and poverty eradication by stressing all needs of the community-from employment, to infrastructure development, to women's rights, to violence prevention. 


\subsection{Gender Roles and Public Employment}

In many public sector projects, women tended to self-select in what are traditionally considered to be "female" work activities, but there were cases in which women took on "male” jobs by setting up their own carpentry or shoe manufacturing shops, or by studying to be electricians or legal aids (Pastoret and Tepepa 2006). Garzón de la Roza reports that while many women working in Jefes still defined themselves within the traditional gender roles, they considered their work to be a form of “social motherhood” (Garzón de la Roza 2006, 32). The primary benefit they reaped from the Jefes experience was a profound transformation in how they perceived their own self-worth (as stated above, this is an essential component of enhancing substantive freedoms). Their work in Jefes was a source of pride, which helped them to acquire more power within the family. While women felt empowered from working outside of the home, they did not completely escape from their gender roles within the home. Often their husbands disapproved of their employment and Jefes, which created a conflict within the household. However, eventually some men learned to "live with" the reality that their wives wanted to and did work outside the home (Ibid., 117). Had the job guarantee not been there, women would have had no recourse to resist the patriarchal attitudes of their spouses.

The gender literature has often emphasized that women, while dedicating many resources to children and family, need to begin to enhance their own outcomes as well. Plan Jefes had notably allowed women to transcend the private-public divide and perceive themselves as more than just parents and domestic servants whose responsibility is to raise children and maintain a household. Women reported that working and serving others was the best example they could give their children, and that they obtained many more valuable rewards from this experience than the monetary aspect (the latter of which women acknowledged was very important to them). Women felt like they had "grown wings” (Garzón de la Roza 2006, 87).

The involvement in community work increased solidarity and transformed neighborhoods. Garzón de la Roza reports that residents found the district of Moron to have markedly changed only a few years after the implementation of Jefes. This is consistent with Tcherneva and Wray's and Pastoret and Tepepa's findings of the transformative effects of Jefes

projects on one of the most destitute regions of Buenos Aires, a region that was known for many years as Cuidad Oculta (i.e., the Hidden City), and which after 4 years of Jefes operation, was renamed to Villa 15, as residents no longer believed to be outside the reach of public policy. 


\subsection{Shortcomings of Plan Jefes}

There were surely problems with the program. Most of them stemmed from the fact that the program was not universal, and therefore did not offer a genuine employment opportunity to all who needed one. For example, some families still managed to enroll more than one household member to participate in the program, which was not allowed by the eligibility criteria. In some cases, politicians used the program for political purposes and secured election votes by promising, but failing, to deliver more Jefes jobs to some communities. Some projects were staffed by people who were not initially eligible for Jefes, but managed to receive the program after organizing political protests and marches demanding from the government such access. Although these projects ultimately served the community, they generated resentment among people who either did not have access to Jefes or who began to associate Jefes workers with the more militant labor organizations. There were also some problems associated with basic management and administration. For example, there were individuals who received the income benefit but did not show up for work-something which women participants explicitly believed undermined the Jefes program and threatened their own participation in the future (Garzón de la Roza 2006, 109)—a rather prescient sentiment.

Due to the very low pay and limited access to the program, poverty remained a significant problem in Argentina even as the economy recovered, although extreme poverty, also known as the indigency rate, was rapidly reduced (Tcherneva and Wray 2005a,b,c). Instead of universalizing Jefes and increasing the Jefes wage, critics argued that the program must be replaced by traditional welfare. One of the reasons why this was considered necessary was because Plan Jefes relied on (what critics called) a “dubious” definition of who is “employable” (Proposed Bill 4334-D-2006). Specifically, it was argued that many women who were not considered to be “employable” had artificially entered the labor market, even though all that was really necessary was simply to provide them with income support. The World Bank recognized that without Jefes, poverty and indigence would have been much worse, and that the program did provide an important income safety net and softened the effect of the crisis on the most vulnerable - which begs the question, if poverty remained a concern, why wasn't the Jefes wage increased and coverage expanded? Note that although the Jefes wage was initially set at 
the minimum wage threshold, its value quickly deteriorated in the aftermath of the crisis, and while the national minimum wage was adjusted upward several times, the Jefes wage was not.

\subsection{Why the Most Vulnerable Women Seem to Benefit Most from Jefes}

Despite all of these reported problems, Jefes was embraced by many women, a narrative which suggests that the poorest and least educated among women benefited the most from the program. As I have argued elsewhere, how individuals perceive their benefits from Jefes depends in part on their level of education and previous work experience (Tcherneva 2005). Those with higher levels of education and skill and who had previously worked in the formal economy appreciated the opportunity to be engaged in some community service, but did not consider Jefes "real work" and were eager to return to their private sector jobs. These were also the men and women who had better chances of being reemployed in the private sector. By contrast, those who had no or little private sector experience (i.e., "the unemployable" according to the government usage of the term) or those who had worked in the informal sector (often as domestic help) valued their work experience tremendously. They believed that it allowed them to connect to social networks and contribute to their neighborhoods. Many of these undereducated women who performed many low-skilled tasks, e.g., kneading bread, preparing food in the community kitchen, and helping with recycling and clean-up efforts, believed that they were being useful to the community. Many wanted more training and education, and many wanted to work longer hours to expand their opportunities for paid private sector work. The training and education component of Plan Jefes, we have often argued, was too small relative to needs, but the program allowed even the least educated poor person to feel useful (Tcherneva 2005; Tcherneva and Wray 2005a,b,c,d). As Minsky (1986) stressed, ELR needs to be a program that takes "workers as they are" and fit the jobs to the workers, not the other way around—something clearly observed under Plan Jefes.

Garzón de la Roza also reports that women who had previous work experience did not feel that they benefited from the on-the-job training and education offered by Jefes because they already had the basic skills. Nevertheless, they felt useful to the community and enjoyed the environment and solidarity in the workplace. In fact, some of those women participated in Jefes precisely to take a break from their domestic chores and to meet their neighbors. Consistent with our findings, some of the better educated individuals and those with previous work experience did not consider Jefes "real work.” But the poor and least educated women felt that 
Jefes had given them essential experience and benefits. Nonetheless, all participants agreed that only paid work enhances dignity, and that receiving traditional income/welfare support brings a certain humiliation to the recipient. Because of the importance of work, all Jefes beneficiaries interviewed expressly felt that all social assistance needed to be "earned with work" (Garzón de la Roza 2006, 111).

Garzón de la Roza reports that Jefes addresses not only the material, but the emotional destitution of people who had been trapped in forced inactivity for too long. Emotional benefits were derived when women found "coherency" and "completeness" in their life, when their existing knowledge was no longer "archived" in their memory but used to help the communities, and when they could escape from demeaning informal sector domestic work and create a "home away from home” in the community center (Garzón de la Roza 2006, 104).

It seems that the poorest women found empowerment and benefited the most from Jefes. Nonetheless, the major obstacles to their participation in Jefes, as it turned out, were not their child responsibilities or poverty, but the social mores of policy makers regarding what was considered "productive" and "unproductive" work, and who should be regarded as employable and unemployable. ${ }^{11}$ These were the attitudes that drove the Jefes reform.

\subsection{The Reform of Plan Jefes and the Introduction of Plan Familias}

Because the most surprising unintended consequence of Plan Jefes was the overwhelming participation of women, the program was viewed as seriously flawed from the very beginning, despite a number of favorable evaluations by the Ministry of Labor and the World Bank (e.g., MTEySS 2002, 2003; World Bank 2002, 2003). And it took only two and a half years for new radical reforms to be initiated by the government. The "activation" of previously excluded population from the labor market was considered to be a major problem. In other words, women who were outside the labor force were considered to be "voluntarily unemployed." Many reformers believed that Jefes now offered artificial incentives to these unemployable women to enter the labor market. During the "reform," government looked at the "activation problem" not from the perspective of an institution that serves the public purpose and the beneficiaries' interests, but from that of private profit-making firms. If women’s work was largely relegated to social provisioning and care, it was considered unproductive. If women lacked previous

\footnotetext{
${ }^{11}$ Debates on what kind of work should be considered productive and unproductive have existed since economists began theorizing production. See Brennan (2006) for a detailed tract on the indefensible nature of this dichotomy.
} 
employment experience and high-school diplomas, they were considered unemployable. Yet experience showed that even the poor and least educated could contribute positively to socioeconomic outcomes. There was widespread recognition that this mass influx of women into the public sector was part of the family survival strategy during the crisis, but there seemed to be no recognition that it also demonstrated the existence of a previously large pent-up demand for paid work under the guise of "forced inactivity."

The "reform" of Jefes began with a government decree in October 2004 that stated as its first order of business the reclassification of the Jefes participants into "employable" and “unemployable” (Decreto 1506/2004). Those who were employable were to be transferred to Seguro De Capacitacion Y Empleo, an unemployment insurance program with a training and labor market insertion component. ${ }^{12}$ Those who were classified as "unemployable” were also considered to be the most vulnerable and structurally disadvantaged individuals and were to enter a welfare program, Plan Familias, which aimed to enhance human development outcomes.

In other words, the first objective of the program was to separate the "employable" from the "unemployable," the second was to promote insertion of the "employable" into private sector employment, and the final was to provide income support to the "unemployable" by divorcing the income benefit from the requirement to participate in community work. As a result, the reform moved the men to the unemployment insurance program and attempted to integrate them into specific industries in the private sector. This integration was primarily accomplished by subsidizing the men's private sector wages for the first six months of employment (MTEySS 2005a). Those who could not be relocated or inserted into private sector employment were covered under Plan Familias. However, the plan explicitly stipulated that only women were eligible to receive the benefit (with the exception of single fathers). A man who worked in Plan Jefes, but was seen as unemployable, was encouraged to leave the program and enroll his wife into Plan Familias. The departure from Jefes was considered to be voluntary, but various “encouragements” and “coercions” were put in place to reduce the Jefes payrolls and move women into Plan Familias. First and foremost, the plan offered higher income support than Jefes. For a family with one child, the income support was 155 pesos; with two, 185 pesos - all the way up to 305 pesos for a family with six children or more (Boletin de Novedades 2007). Jefes, by contrast, only provided 150 pesos per month. There was also an

\footnotetext{
${ }^{12}$ The goal of this transfer was to promote a "true culture of work" (Decreto No. 1506/2004).
} 
active public campaign that "marketed" the Plan Familias option to women. As a result, the program grew from 240,000 people enrolled in 2005 to 700,000 people by 2007 (Datos Nacionales 2007).

Plan Familias itself had three main components, which were in part funded by a loan from the Inter-American Development Bank (IADB 2005). ${ }^{13}$ First, it aimed to provide a nonwage income to poor and uneducated mothers. The targeted group was mothers who had not completed secondary education and who had two children or more. Vulnerable childless women who lived in poverty (regardless of their level of education) did not qualify for this program. The basic eligibility requirements for receiving the income stipulated that women's children: 1 ) enroll in school; 2) receive the required vaccinations; and 3) receive periodic health checkups from birth to age 19 .

The second component allocated funding for improving the local schools and other educational opportunities of children. Funds were also directed to the organization of seminars, training schedules, and educational courses for their mothers in order to: 1) increase their employability; 2) enhance their understanding of their civil, social, and political rights; 3) teach them personal autonomy; and 4) coach them on how to avoid drug addiction and violence. Women could choose to enroll in these workshops, but participation was not a precondition for welfare eligibility. $^{14}$

The final component of the program allocated funds for a "communication and information strategy" to explain the benefits of this program to women, inform them of the available training opportunities, improve public opinion of the program, fortify administrative oversight and program management, and, specifically, to implement the easy and efficient transfer of Jefes participants into Familias.

As noted above, in some cases, where Jefes projects were still operating, women continued to go to their places of work, but the government's effort to "encourage" them to leave Jefes was significant. This “marketing strategy” was, in part, motivated by the results of pilot efforts to transfer Jefes workers to Plan Familias. Two such pilot programs were launched-one in the district of Ituzaingó, Bs.As., and the other in Santa Fé. The IADB argued

\footnotetext{
${ }^{13}$ Technically, all programs were being financed in pesos in their entirety, as Argentina had now regained its currency sovereignty. The World Bank, however, still provided dollar loans to Argentina, or rolled over previous loans on the rationale that it was partially "funding" Plan Familias.

${ }^{14}$ If poor mothers completed their secondary education as a result of enrolling in these programs, they would still qualify for Plan Familias.
} 
that these pilot programs performed “acceptably” (IADB 2005, 29). In Ituzaingó, 94 percent of the population that was considered unemployable was successfully persuaded to transfer to Plan Familias, but in Santa Fé, less than 50 percent of the eligible population chose to leave Jefes (Ibid.).

Because of these pilot results, it was recommended that the government expand its public relations efforts to explain the intended benefits of Familias to women participating in Jefes. In sum, paternalistic policies which presume to know what is better for the poor than the poor themselves drove the reform of Jefes, propelled by gender stereotypes about what type of work is productive and unproductive and which individuals are employable and unemployable.

Plan Jefes was criticized for not considering the heterogeneity of the households participating in the program. In particular, women who had many children were considered to be especially vulnerable to conditions of poverty and should not have been required to work for their income support. Thus, Plan Familias intended to provide nonwage income that grows with the number of minors in the family, thereby improving children's outcomes. Research shows that child outcomes are indeed enhanced when policies target women, as women tend to allocate proportionately more of their income toward children's health, nutrition, and education than men do (Thomas 1990). This is one reason why, Plan Familias's eventual replacement by a universal child allowance policy was a positive development, but in those cases where poor mothers with kids wanted to work, the opportunity was no longer there. Plan Familias removed that opportunity and replaced it with a basic income guarantee that failed to help alleviate gender disparities.

Advocates of Plan Familias also argued that the program better targeted women's health and education outcomes. Women, for example, could now choose when and where to attend the workshops aimed at improving their own education and skills. And if management of the available community service projects were improved, these vulnerable women could be served better by Familias than by Jefes.

These latter arguments for replacing Jefes with Familias, however, are unconvincing. If the administration and institutional support for Jefes projects were deficient (and there are good reasons to think that they were), the "reform" could have focused on improving them without canceling the program. Plan Familias, by contrast, has dedicated significant funds for improvements in the operation of social services, but has now replaced their provisioning with higher-wage/traditional public sector workers, rather than allowing the unemployed to 
participate in the process (which they did under Jefes). Secondly, if the wage was considered too low, instead of cancelling Jefes, the wage could have been raised and supplemented with a universal child support component similar to Plan Familias. Women want to work and feel empowered from working in and for the community. An educational workshop may be able to teach them about their civil, social and political rights, but Jefes allows them to exercise them. Women can learn about empowerment in the classroom or they can be given tangible opportunities that empower. Workshops for violence prevention and information about shelters for the abused are all desirable and much needed, but Jefes had already begun to offer them. Furthermore, by actively participating in the provision of these services, women become not only "patients" of violence prevention, but “agents” of change. The expansion of eligibility criteria to include frequent health checkups through age 19 could have easily been added to Jefes. Pay could have been increased and, therefore, child outcomes would have improved. Women had more power over their material resources in Jefes because they controlled both their own income and output.

With Jefes, the burden of unpaid work associated with child rearing was not only reduced, but care was explicitly recognized as a function of the larger community and not strictly of the individual family unit. This important aspect of the socialization of care has been long emphasized in the Feminist literature (Folbre 2001; Archer 2003). A stakeholder society and participatory democracy are enhanced via public service. Plan Familias made no explicit provisions for alleviating unpaid care work within the household that would change the dynamics that relegate care work as the sole responsibility of the mother. Thus, even though the Jefes requirement to work was considered punitive for mothers with many children, it is unclear how these same mothers would be able to attend the educational workshops Plan Familias offered when there were no direct measures to reduce their burden of unpaid work (Golbert 2007, 147). ${ }^{15}$ By contrast, because through Jefes women themselves proposed and designed many of the community projects, the care burden was alleviated by the partial socialization of care work.

In sum, Plan Familias was born out of the belief that "unemployable” and previously “inactive” women, who were "artificially activated” by Jefes, should return to inactivity. The

\footnotetext{
${ }^{15}$ Note, for example, that the Mexican welfare program Oportunidades has in fact increased women's unpaid work, since the poor infrastructure and lack of services in near proximity had forced them to travel great distances to fulfill their eligibility requirements and attend health facilities, educational and nutrition workshops, or to simply receive their payments (ECLAC 2007 cited in Antonopoulos 2008).
} 
actual implementation of the program was rationalized by the idea that many women in extreme poverty did not benefit from Jefes. The program did not enhance human development outcomes, and added to the onerous burden of work due to the requirement to engage in community service. Few policy makers recognized that the low Jefes wage and deficient public services were the reasons why serious progress toward reducing poverty was not made. Instead, many claimed that having to work in the public sector as well as in the home is what kept many women in poverty. For this reason, the reform aimed to give higher income support, eliminate participation from its requirements, and shut down many Jefes projects. ${ }^{16}$

Divorcing the income benefit from the employment requirement was a way of separating those who were considered "employable" from those who were viewed as "unemployable." The stipulation that only women can be eligible for Plan Familias further reinforced the conservative view that women's work in Jefes was generally unproductive. The reform, therefore, called for sending them back to the home with a welfare check, providing them with information about remedial courses and training, but without the guarantee of a job available to them should they want one. This reform was essentially based on the old ideology that government policies must induce or nudge women to change their own behavior and character to become “employable” if they want private sector work. Women’s roles as mothers and spouses were reinforced by this reform, while at the same time attempts were made to help their husbands transition to private sector employment.

\section{PUBLIC EMPLOYMENT AND INCOME TRANSFERS: SOME CONCLUDING THOUGHTS}

Employment guarantee programs have often been criticized for perpetuating a paid-work society that unjustly exempts the privileged and wealthy from the requirement to work, while forcing the poor to work for their subsistence. In the literature on basic incomes, in particular, it has been argued that an income guarantee will move the world to a post-work society where an individual's pursuits will be linked not to the need to earn the means of subsistence, but to the freedoms that basic income support affords (e.g., Aronowitz and DiFazio 1994; Aronowitz and Cutler 1998; Fitzpatrick 2003).

\footnotetext{
${ }^{16}$ To counter this effect Plan Familias allocated part of its budget for the establishment of education and health centers in poor communities, to fill the gap (IADB 2005). These were to be staffed not by community members, but by higher wage and more qualified personnel. All of these enhancements could have been made to the Jefes Plan.
} 
In the modern monetized world, however, the poor and the unemployed want paid work. The Argentinean example showed that paid work matters to poor mothers and that visions of a post-work society are not their visions. Poor mothers want to participate in mainstream society, contribute to private market and community production, and receive wages. At the same time, poor mothers feel the pressing need for mainstream society to recognize their care work and community work as useful. Women also understand that income alone does not empower. Social mores dictate that genuine empowerment comes from earned income, not charitable contributions. Although nonwage income entitlements to women attempt to recognize household work as socially-useful work deserving of financial support in a monetized society, they do not carry the the same benefits women report from engaging in paid employment, nor do they help break the gender stereotypes of division of responsibilities within the household.

For a genuine transformation within the marketplace or the household, an active agent of change is needed. Income support programs are passive agents of change-they make their recipients invisible and hidden from the sphere of most socioeconomic life. Cash transfer supporters presume that the liberties afforded to the recipients of a basic income guarantee are so great that women will be able to extract themselves from the onerous conditions of poverty, the burden of unpaid work, and their dependence on men's earning to begin active participation in the community, labor markets, or political life. Even if this were true, there is still no guarantee that such opportunities will, in fact, exist for the income recipients. Basic income supporters almost automatically assume that, as long as the universal basic income is guaranteed, a market solution that will supply these opportunities will emerge. Women who get income support, training, and education are promised the fruits of paid work, but are not necessarily guaranteed to reap them. There is no economy today that operates near full employment, as there is not enough effective demand for the complete absorption of the unemployed - thus improvements in human capital do not guarantee access to economic opportunity, nor do they ensure that substantive individual freedoms will be enhanced.

Even if income afforded certain freedom to individuals, transformative changes occur when individual action is harnessed by those institutions that can propel the collective interests forward. The ELR is an institution that puts human needs first as it redefines "efficient” from what is "profitable" to what is "useful” (see also Archer 2003 on this distinction). It engages its participants directly in the goal of advancing the public purpose and is, therefore, a program that promotes inclusion. Thus, when designing fiscal policy the inclusion/exclusion nexus matters. 
Income alone does not create inclusion into socioeconomic and political life, but participation does. This is why I have argued that the best way to combine the important goals of basic income and job guarantees is to design a universal guaranteed participation income program in the form of an ELR, supplemented by a universal child allowance and income support for the sick and the retired (Tcherneva 2006; 2009). Any social reformer must take seriously the vile effects of the condition of forced inactivity that is unemployment.

The argument that it is highly undesirable to activate women through the ELR program (by "artificially" bringing them into the labor market) is parochial. Women often serve as a buffer to complement earning strategies of families during times of crisis. ${ }^{17}$ In terms of the power relationship within the household, women may be able do so because during crises their husbands may allow them to participate in work outside of the home, but when family earnings are adequate, women are thrust into inactivity by social mores, husbands' attitudes, or simple lack of employment opportunity. The ELR program, by contrast, recognizes the right of all men and women to participate in a universal employment program that redefines civic society. Men’s resistance to women's participation may be less if ELR is accessible to all, but furthermore, the very existence of a guaranteed employment opportunity will provide the teeth in women's bite when they demand work outside of the home. ${ }^{18}$ Again, it is important to note that ELR is not a coercive program; it offers income and the opportunity to work. Homemakers who prefer to stay at home will feel no obligation to join such a program and can enjoy the benefits of the universal child allowance which supplements the public employment strategy.

Finally, it is important to stress that ELR must be a universal program, even though it can deliver key benefits especially to women. First, from the perspective of inclusion and human rights, equal access to all is essential (CELS 2003, 34). Neither Plan Jefes nor Plan Familias offered equal access. Secondly, as noted earlier, only a truly universal program can redress labor market precariousness more effectively. Seguino and Grown (2006) have persuasively argued that to enhance gender equality, pro-wage/pro-full employment policies are needed. There are other reasons why a universal ELR will help women's causes. If ELR is not universal, it will create social antagonism and reactionary sentiment, as demonstrated by the Jefes experience. If Jefes were designed as a universal program, it would likely have produced

\footnotetext{
${ }^{17}$ Note that the "buffer theory," which argues that women often act as a buffer workforce for the family, is not universally believed, although in the case of Argentina it seems to hold.

${ }^{18}$ Seguino 2007 finds that men have less resistance to female empowerment as the economic pie expands.
} 
more equitable distribution between male and female participants in the program. Additionally, because Jefes was not universal, unemployment in Argentina was not wiped out, even though it declined immediately and dramatically.

If equal access were granted to all, women would likely have suffered less stigmatization than they did. Those who participated in public employment, however, would not be stigmatized as much as those receiving welfare; although it must be noted that welfare recipients are often largely invisible. Because of this, society does not always rally opposition to welfare programs, even if they are more expensive or less effective than public employment schemes. Thus, it is very important that the visible public output produced by women and men is both useful and needed, but also adequately acknowledged as such.

A universal Jefes will also produce a faster formalization of informal activity and stronger countercyclical effect. One problem remains, however: men still enter private sector employment in larger numbers than do women ${ }^{19}$ (MTEySS 2005b), indicating various barriers to entry into private sector jobs (discrimination, lack of prior opportunities, or employment experience) or simple self-selection-if women prefer the proximity to the home. Thus, ELR must be accompanied with fair hiring laws, affirmative action, and other provisions. ELR cannot correct all discrimination in hiring practices, but ELR could potentially ensure that private employers hiring from the public sector pool do so on the basis of skill and not on that of gender. Furthermore, ELR itself can be designed in a way that increases the "employability" of women, but because it guarantees the job opportunity in the public sector, it also allows women to refuse private sector employment in subpar conditions.

Finally, in Jefes, the products and earnings from public employment were not controlled by men. Women produced, distributed, and sold their own output. They kept portions of their earnings to reinvest in the co-op or microenterprise, or to spend on household and children needs. While women clearly believed to be empowered by the job opportunity, it is quite possible that such empowerment may emasculate their spouses, engendering resentment towards working in the public sector. This is why universalization, rather than elimination, of the Jefes Program would have been a better course of action. Men have less resistance to female employment when both genders have access to the same opportunity, even if men do not end up

\footnotetext{
${ }^{19}$ Although women comprised about 74 percent of Jefes participants in 2005, only 34 percent of all Jefes who found private sector employment after enrolling in the program were women (MTEySS 2005b).
} 
taking proportionate advantage of these opportunities. ${ }^{20}$ In the modern context, it is less likely to improve the employment practices of multinational corporations sufficiently quickly in order to allow women equal employment opportunities. Although such a goal is of utmost importance for more egalitarian labor market conditions, one step towards achieving it is by providing employment opportunities to men and women in the public sector. So long as these public sector jobs have a gender-informed design, they will be able to incorporate the care economy in the public sphere and help redefine the meaning of work away from strict market utility, towards social usefulness. Such a re-conceptualization of work and of the public sector domain may be necessary for implementing sustainable long-term policies for macroeconomic stabilization and full employment.

\footnotetext{
${ }^{20}$ Note that in the case of Jefes, men did have access to the program but chose not to participate, and thus designated their wives to be the head of the household for the purposes of program eligibility.
} 


\section{REFERENCES}

Antonopoulos, R. 2007. "The Right to a Job, the Right Types of Projects: Employment Guarantee Policies from a Gender Perspective.” Working Paper No. 516. Annandale-onHudson, NY: The Levy Economics Institute of Bard College.

— . 2008. “The Unpaid Care Work-Paid Work Connection.” Working Paper No. 541. Annandale-on-Hudson, NY: The Levy Economics Institute of Bard College.

Archer, M. 2003. “The Meaning of the Primacy of Labor over Capital” in Forum on the Meaning of the Priority of Labor. Vatican City, Vatican City State: The Pontifical Academy of Social Sciences.

Aronowitz, S. and J. Cutler. 1998. Post-Work. London, U.K.: Routledge.

Aronowitz, S. and W. DiFazio. 1994. The Jobless Future. Minneapolis, MN: University of Minnesota Press.

Atkinson, A. B. 1995. Public Economics in Action: The Basic Income/Flat Tax Proposal. Oxford, UK: Oxford University Press.

Bakker, I. 2002. Fiscal Policy, Accountability and Voice: The Example of Gender Responsive Budget Initiatives. Human Development Report Office Occasional Paper. New York, NY: UNDP.

Beneria, L. and S. Feldman. 1992. Unequal Burden: Economic Crises, Persistent Poverty, and Women's Work (eds.) Oxford, UK: Westview Press.

Bergman, B. 1986. The Economic Emergence of Women. New York, NY: Basic Books.

Boletin de Novedades. 2007. Programa Familias por la Inclusion Social, Ministerio de Desarrollo Social.

Brennan, D. 2006. “Defending the Indefensible? Culture's Role in the Productive / Unproductive Dichotomy.” Feminist Economics 12(3). July: 403-425.

Çagatay, N., and K. Ertürk. 2004. "Gender and Globalisation: A Macroeconomic Perspective.” Technical background paper for the Final Report of the World Commission on the Social Dimension of Globalization A Fair Globalization: Creating Opportunities for All. Geneva, Switzerland: ILO. 
Çagatay, N. and S. Ozler. 1995. "Feminization of the Labor Force: The effects of Long-term Development and Structural Adjustment.” World Development 23(11): 1883-1894.

CELS. 2003. “Plan Jefes y Jefas: ¿Derecho social o beneficio sin derechos?” Buenos Aires, (mayo), Centro de Estudios Legales y Sociales.

Datos Nacionales. 2007. Programa Familias por la Inclusion Social, Ministerio de Desarrollo Social, Argentina.

Decreto n ${ }^{0}$ 1506/04: http://www.desarrollosocial.gov.ar/Planes/PF/dec_1506_04.pdf, accessed May 1, 2007.

ECLAC. 2007. Economic Commission for Latin America and the Caribbean. "Women's Contribution to Equality in Latin America and the Caribbean.” Paper prepared by Women and Development Unit of the ECLAC for the Regional Conference on Women in Latin America and the Caribbean, Ecuador, August 6-9.

Elson, D. 1995. Male Bias in Economic Development. Manchester, U.K.: University of Manchester Press.

- 2006. Budgeting for Women's Rights; Monitoring Government Budgets for Compliance with CEDAW. New York, NY: United Nations Development Fund for Women UNIFEM.

Finnoff, K. and A. Jayadev. 2006. "Feminization and the Labor Share of Income.” GEM-IWG Working Paper No. 06-4, July.

Fitzpatrick, T. 2003. After the New Social Democracy. Manchester, U.K.: Manchester University Press.

Folbre, N. 2001. The Invisible Heart: Economics and Family Values. New York, NY: The New Press.

Fullwiler, Scott T. 2003. "Further Simulation of an Employer of Last Resort Policy.” Center for Full Employment and Price Stability. Working Paper \# 27 (August). Available at http://www.cfeps.org/pubs/

- 2005. "Macroeconomic Stabilization through an Employer of Last Resort.” Center for Full Employment and Price Stability. Working Paper \# 44 (August). Available at http://www.cfeps.org/pubs/

Galston, W. 2001. “What About Reciprocity?” In J. Cohen and J. Rogers (eds.) What's Wrong with a Free Lunch? Boston, MA: Beacon Press.

Garzon de la Roza, G. 2006. “Continued Struggle for Survival: How Plan Jefes y Jefas affected poor women’s lives in Greater Buenos Aires, 2002-2005.” Georgetown University 
Development Management and Policy Program Collection. http://hdl.handle.net/1961/4188, accessed August 15, 2008.

Golbert, L. 2007. “Aprendizajes del Programa de Jefes y Jefas de Argentina.” In Irma Arriagada (ed.) Gestión y financiamiento de las políticas que afectan a las familias. Santiago, Chile: CEPAL Seminar and Conference Proceedings.

Grown, C. 2006. “Quick Impact Initiatives for Gender Equality: A Menu of Options.” Working Paper No. 462. Annandale-on-Hudson, NY: The Levy Economics Institute of Bard College.

Hartmann, H. 1998. “The Economic Emergence of Women: Bergmann’s Six Commitments.” Feminist Economics 4(3): 169-180.

Harvey, P. 1995. "Fashioning a Work- Based Strategy for Welfare Reform Based on International Human Rights Doctrine.” Journal of Public Health Policy 16: 269.

Hirway, I. 2006. "Enhancing Livelihood Security through the National Employment Guarantee Act: Toward Effective Implementation of the Act." Working Paper No. 437. Annandaleon-Hudson, NY: The Levy Economics Institute of Bard College.

IADB. 2005. "Support for the Plan Familias Program, Argentina.” Inter-American Development Bank Loan Proposal AR-L1006.

Inglehart, R. and P. Norris. 2003. Rising Tide: Gender Equality and Cultural Change around the World. Cambridge, U.K.: Cambridge University Press.

Koggel, C. M. 2003. “Globalization and Women’s Paid Work: Expanding Freedom?” Feminist Economics 9(2-3): 163-183.

Kostzer, D. 2008. "Argentina: A Case Study on the Plan Jefes y Jefas de Hogar Desocupados, or the Employment Road to Economic Recovery.” Working Paper No. 534. AnnandaleOn-Hudson, NY: Levy Economics Institute.

Majewski, R. 2004. "Simulating an Employer of Last Resort Program.” in Argyrous, Forstater, and Mongiovi (eds.) Growth, Distribution, and Effective Demand: Alternatives to Economic Orthodoxy, Essays in Honor of Edward J. Nell. Armonk, NY: M.E. Sharpe Inc.

Minsky, H.P. 1986. Stabilizing an Unstable Economy. New Haven, CT: Yale University Press.

Mitchell, W. F. 1998. “The Buffer Stock Employment Model.” Journal of Economic Issues 32(2): 547-555.

Mitchell, W. F., and M. J. Watts. 2004. "A Comparison of the Macroeconomic Consequences of Basic Income and Job Guarantee Schemes.” Rutgers Journal of Law and Urban Policy 2(1): 1-24. 
Mosler, W. B. 1997-98. "Full Employment and Price Stability.” Journal of Post Keynesian Economics 20(2): 167-182.

MTEySS. 2002. Impacto Macroeconómico Del Programa Jefas y Jefes De Hogar, Buenos Aires, Argentina: Ministerio de Trabajo, Empleo y Seguridad Social, Agosto.

2003. Plan Jefas y Jefes de Hogar Desocupados: Un año de gestión, Mayo 2002 Mayo 2003, Buenos Aires, Argentina: Ministerio de Trabajo, Empleo y Seguridad Social.

— 2005a. "Segunda Evaluación del Programa Jefes de Hogar. Resultados de la Encuesta a beneficiarios”. Buenos Aires, Argentina: Ministerio de Trabajo, Empleo y Seguridad Social.

— . 2005b. "Sistema de información y monitoreo y evaluación de programas de empleo." Buenos Aires, Argentina: Ministerio de Trabajo, Empleo y Seguridad Social.

Nussbaum, M. 1999. Sex and Social Justice. Oxford, U.K.: Oxford University Press.

—. 2003. “Capabilities as Fundamental Entitlements: Sen and Social Justice.” Feminist Economics 9(2/3): 33-60.

Pastoret, C. and M. Tepepa. 2006. “Community Development and ELR: A Gender-Aware Perspective and the Jefes and Jefas Program in Argentina.” In D. Papadimitriou (ed.) Employment Guarantee Policies: Theory and Practice. The Levy Economics Institute Conference Proceedings, presented during Oct. 13-14, 2006 conference on the Employer of Last Resort.

Van Parijs P. 1991. "Why Surfers Should Be Fed: The Liberal Case for an Unconditional Basic Income.” Philosophy and Public Affairs 20 (spring): 101-31.

Proposed Bill 4334-D-2006, 104, 07/08/2006. The Creation of the System of Social Protection, Parliamentary proceedings, H.Cámara de Diputados de la Nación. $\mathrm{N}^{\mathrm{o}}$ de Expediente 4334-D-2006. Creacion de la Red de Proteccion Social (RPS).

Seguino, S. 1997. "Export-Led Growth and the Persistence of Gender Inequality in the Newly Industrialized Countries.” In J. M. Rives and M. Yousefi (eds.) Economic Dimensions of Gender Inequality: A Global Perspective. 11-34. Westport, CT: Praeger.

- 2007. "Plus Ça Change? Evidence on Global Trends in Gender Norms and Stereotypes.” Feminist Economics 13(2): 1-28.

Seguino, S. and C. Grown. 2006. "Feminist-Kaleckian Macroeconomic Policy for Developing Countries.” GEM-IWG Working Paper 06-15. November.

Sen, A. 1987. The Standard of Living. Cambridge, U.K.: Cambridge University Press. 
—. 1999. Development as Freedom. New York, NY: Alfred A. Knopf.

Standing, G. 1999. “Global Feminization Through Flexible Labor: A Theme Revisited.” World Development 27(3): 583-602.

—. 2008. “How Cash Transfers Promote the Case for Basic Income.” Basic Income Studies 3(1): 1-30.

Tcherneva, P. R. 2005. “The Art of Job Creation: Promises and Problems of the Argentinean Experience.” C-FEPS Special Report 05/03. Kansas City, MO: Center for Full Employment and Price Stability of the University of Missouri-Kansas City.

— 2006. "Universal Assurances in the Public Interest: Evaluating the Economic Viability of Basic Income and Job Guarantees.” International Journal of Environment, Workplace, and Employment 2(1): 69-88.

- 2009. "Evaluating the Economic and Environmental Viability of Basic Income and Job Guarantees.” In P. Lawn (ed.) Environment and Employment: A Reconciliation. London: Routledge.

—. 2012. "Inflationary and Distributional Effects of Alternative Fiscal Policies: An Augmented Minskian-Kaleckian Model.” Working Paper (forthcoming). Annandale-onHudson, NY: The Levy Economics Institute of Bard College.

Tcherneva, P. R. and L. R. Wray. 2005a. "Common Goals - Different Solutions: Can Basic Income and Job Guarantees Deliver Their Own Promises?” Rutgers Journal of Law and Urban Policy 2(1): 125-166.

—. 2005b. "Employer of Last Resort: A Case Study of Argentina’s Jefes Program.” CFEPS Working Paper No. 41. Kansas City, MO: Center for Full Employment and Price Stability of the University of Missouri-Kansas City.

. 2005c. “Is Argentina’s Jefes de Hogar an Employer of Last Resort Program?” C-FEPS Working Paper No. 43. Kansas City, MO: Center for Full Employment and Price Stability of the University of Missouri-Kansas City.

_ 2005d. "Public Employment and Women: The Impact of Argentina's Jefes Program on Female Heads of Poor Households” Working Paper No. 519. Annandale-on-Hudson, NY: The Levy Economics Institute of Bard College.

Thomas, D. 1990. “Intra-Household Resource Allocation: An Inferential Approach.” The Journal of Human Resources 25(4): 635-664.

Walby, S. 1997. Gender Transformations. London, U.K.: Routledge.

—. 2002. “Feminism in a Global Era.” Economy and Society 31(4): 533-557. 
White, S. 2003. The Civic Minimum. Oxford, U.K.: Oxford University Press.

Widerquist, K. 1999. “Reciprocity and the Guaranteed Income.” Politics and Society 33(3): 386-401.

World Bank. 2002. "Project Appraisal Document on a Proposed Loan in the Amount of US\$600 Million to the Argentine Republic for the Jefes De Hogar (Heads of Household) Program Project.” World Bank Report No. 23710-AR. October 22.

World Bank. 2003. "Implementation Completion Report (SCL-43660) on a Loan in the Amount of US\$284 Million Equivalent to the Argentine Republic for a Third Social Protection Project.” World Bank Report No. 26134-AR. June 30.

World Bank. 2007. "Confronting the Challenges of Gender Equality and Fragile States.” Global Monitoring Report. Washington, D.C.: The World Bank.

Wray, L. R. 1998. Understanding Modern Money: The Key to Full Employment and Price Stability. Cheltenham, U.K.: Edward Elgar.

Wray, L.R. and Forstater, M. (2004) '“Full Employment and Social Justice,” in D. Champlin and J. Knoedler (eds.) The Institutionalist Tradition in Labor Economics. Armonk, NY: M.E. Sharpe. 